\title{
A cross sectional study on the immediate response and mental health of the people during the initial phase of covid-19 lockdown in Chennai
}

\author{
K Monicka ${ }^{1 *}$, Nirranjana Ganesh ${ }^{2}$, S P Nithya ${ }^{3}$ \\ ${ }^{1}$ Assistant Professor, ${ }^{2,3}$ Third year MBBS Students, Dept. of Psychiatry, ESIC Medical College \& PGIMSR, Chennai, Tamil Nadu, India
}

*Corresponding Author: K Monicka

Email: medicomons83@yahoo.co.in

\begin{abstract}
Introduction: On 24th March 2020, a 21-day nationwide lockdown was announced by the prime minister of India. This was a beginning of more phases of lockdown. People had to stay indoors, with worries about an uncertain future, about the well-being of near and dear, the lockdown added to the stress of the pandemic.

Aims and Objectives: Our study aims at finding out the responses of the residents of Chennai in the immediate aftermath of the initial 21 day lockdown and to assess their mental health at that time.

Materials and Methods: The study design was cross-sectional with a sample of 800. An online questionnaire was created using Google forms and was circulated via social media platforms. Post online consent, the participants filled up the questionnaire which included two psychiatric scales: ADNM-20 and HADS. IBM SPSS Software version 25 was used for analysing data.

Results: Out of the total 800, 215(26.84\%) participants had adjustment disorder, 109(13.6\%) had anxiety and 50(6.24\%) had depression. Significant mean difference was observed between males and females in the scores ADNM20 $(t=81.5, p=0.0290)$, ANXIETY $(t=27.5$, $\mathrm{p}=0.010)$, DEPRESSION $(\mathrm{t}=25.9, \mathrm{p}=0.039)$. For occupations, a significant group difference was on ANXIETY scale $(\mathrm{F}=2.427, \mathrm{p}=0.047)$ and DEPRESSION scale $(\mathrm{F}=3.994, \mathrm{p}=0.003)$. A significant group difference was observed in adjustment $(\mathrm{F}=2.973, \mathrm{p}=0.019)$ and anxiety $(\mathrm{F}=2.786, \mathrm{P}=0.026)$ for time spent on watching corona news. Financial worries showed a significant association with adjustment (chi $=28.128, \mathrm{p}=0.0001)$, anxiety $(\mathrm{chi}=50.252, \mathrm{p}=0.0001)$ and depression $(\mathrm{chi}=16.661, \mathrm{p}=0.002)$. A significant association was found $)$. A significant association was found between participants picking a fight with a family members and adjustment disorder $(\mathrm{chi}=64.328$, $\mathrm{p}=$ 0.0001 ), anxiety (chi=78.089, $\mathrm{p}=0.0001)$ and depression (chi=54.667, $\mathrm{p}=0.0001)$.

Conclusion: This study findings will prompt the policymakers, to intervene and prioritize mental health resources and substance use services, as these will be needed on a longer term. Domestic violence incidents that increased in Chennai during the lockdown have been highlighted in our study.
\end{abstract}

Keywords: Lockdown, Corona related news, Domestic violence.

\section{Introduction}

An epidemic occurring worldwide is Pandemic. ${ }^{1}$ WHO declared the ongoing COVID-19 as a pandemic on $11^{\text {th }}$ of March 2020. As of 15 September 2020, world over, $2,98,65,000$ people are affected with $\sim 9,41,000$ deaths and $51,20,000$ cases are confirmed with 83,000 deaths in India. ${ }^{2}$ This has become an unexpected global public health challenge. On 24th March 2020, a 21-day nationwide lockdown was announced by the prime minister of India. This was a beginning of more phases of lockdown. People had to stay indoors, with worries about an uncertain future and about the well-being of near and dear, thus the lockdown added to the stress of the pandemic. According to Dr Hans Henri P Kluge, we all must cooperate as a community, to face this situation. ${ }^{4}$ Being social is a human tendency that facilitates social interaction, and thus, when our movements are curbed, mental distress results. ${ }^{5}$ This pandemic has led to a lot of psychological effects like anxiety and adjustment problems. The compulsory stay at home life has affected different aspects of people's life. The fear of contracting the infection was multiplied by the unavailability of resources, during the lockdown. The poignant impact of being locked down, and the weight of the resulting solitude generated waves of fear, anxiety, depression in people of all ages and groups. The doubt is increasingly testing the psychological resilience of the masses and thus makes it even more necessary to analyse the mental health of people in general and within the different sectors in specific.

This study collects information on how the various factors affect the mental status of a person during the initial period of the lockdown, so that it can be used to address the mental health of the public in future.

\section{Aims and Objectives}

Our study aims at finding out the responses of the residents of Chennai in the immediate aftermath of the initial 21-day lockdown and to assess their mental health at that time.

\section{Materials and Methods \\ Study design \\ A cross sectional study.}

\section{Sample size}

800.

Sample size was calculated based on the study variables, total sample size required is 645 , considering 15 frequency per variable, question no 8 to question no 50 are the study variables in the questionnaire. Accounting for a $20 \%$ nonresponsive rate, a total sample of 800 was attempted.

\section{Inclusion criteria}

1. All people aged above 18 years, and living in Chennai,

2. Able to read English 
3. People with internet connection on their phone

\section{Exclusion criteria}

1. People tested positive for COVID-19 and on treatment.

2. People in the isolation ward.

3. People in isolation/observation because of possible contact history.

4. People who have been cured from COVID-19 after treatment

5. People unwilling and not providing informed consent for the study.

6. People on treatment for known psychiatric disorders.

\section{Procedure}

Institutional ethical committee approval was obtained on a fast-track basis on 03.04.2020. An online questionnaire created using Google forms was circulated via social media from 04.04.2020 to 04.05.2020. After giving consent, the participants of the survey filled up their questionnaires.

\section{Instruments used}

There were four sections in the questionnaire.

First two sections of the form: The first part had the demographic and employment details of the participant, while the second part had questions specific to the lockdown, regarding various activities done from home during that time. These questions were meant to help in finding the social status of the participant, as well as understand the changes in their lifestyle caused due to the lockdown.
The third and fourth section of the questionnaire: 2 psychiatric scales: ADNM-20 and HADS. They were used to assess the current mental status of the participant.

The ADNM -20 (Adjustment Disorder New Module20): is a self-report questionnaire that consists of a stressor list and an item list. Stressor list helps to identify the stressor and item list measures the symptom in response to the stressor. Since the stressor, as per this research is, the lockdown, the item list alone is used for symptom evaluation. This scale shows convergent and discriminant validity for anxiety symptoms. ${ }^{6}$ ADNM-20 scale was used because studies show that it can be used as a screening tool for anxiety ${ }^{7}$ and as ADNM-20 results have proven to show internal stability with its subscales. ${ }^{8}$

\section{HADS scale}

The HADS (Hospital Anxiety and Depression Scale) is a fourteen-item scale that consists of 2 sections with 7 issues each, to assess anxiety and depression. National Institute of Health and Care Excellence (NICE) has recommended HADS for diagnosis of depression and anxiety. ${ }^{10}$ This scale performs well in assessing the symptom of anxiety disorders and depression in patients attending hospitals and in the general population. These 2 scales have high value for Cronbach's alpha with the coefficient of 0.94 for ADNM-20 and 0.83 for HADS. $^{9}$ Combined analysis using these 2 scales provides a more specific result.

\section{Statistical analysis}

Data was analysed with the help of SPSS version25, IBM Corp., Armonk, NY, USA. T test, ANOVA, Chi-square tests were carried out to make inferences.

\section{Results}

Table 1: Depicts the Socio-demographic profile of the study

\begin{tabular}{|c|c|c|c|}
\hline Sociodemographic variable & Groups & Percentage & No. of individuals \\
\hline \multirow[t]{4}{*}{ Age } & $18-35$ & $51.18 \%$ & 410 \\
\hline & $36-50$ & $28.21 \%$ & 226 \\
\hline & $51-65$ & $17.85 \%$ & 143 \\
\hline & $>65$ & $2.74 \%$ & 22 \\
\hline \multirow[t]{2}{*}{ Sex } & Male & $45.71 \%$ & 366 \\
\hline & Female & $54.05 \%$ & 434 \\
\hline \multirow[t]{5}{*}{ Occupation } & Healthcare & $16.35 \%$ & 131 \\
\hline & IT & $9.61 \%$ & 77 \\
\hline & Student & $26.21 \%$ & 210 \\
\hline & Homemaker & $11.73 \%$ & 94 \\
\hline & Others & $36.08 \%$ & 289 \\
\hline \multirow[t]{4}{*}{ Marital status } & Married & $57.3 \%$ & 459 \\
\hline & Single & $40.9 \%$ & 328 \\
\hline & Widowed & $1.12 \%$ & 9 \\
\hline & Divorced & $0.62 \%$ & 5 \\
\hline
\end{tabular}

*Of 801 people, $410(51.18 \%)$ people were between 18-35 years, 226(28.31\%) people were between $36-50$ years, $143(17.85 \%)$ were between 51-65 years, $22(2.74 \%)$ were between $>65$ years and $+366(45.71 \%)$ were males, $434(54.05 \%)$ were females. \$ In the occupation they were involved, 131(16.35\%) were healthcare, $77(9.61 \%)$ are IT, 210(26.1\%) are students, 94(11.74\%) are homemakers, others 289(36.78\%), **459(57.3\%) were married, 328(40.9\%) were single, $9(1.12 \%)$ were widowed, $5(0.62 \%)$ were divorced. 
Table 2: Criteria for adjustment disorder, anxiety and depression based on the scores of ADNM -20 scale and HADS

\begin{tabular}{|l|c|c|c|}
\hline Diagnosis of adjustment of disorder & $\begin{array}{c}\text { Criteria based on } \\
\text { scores }\end{array}$ & $\begin{array}{c}\text { Number } \\
\text { (Total=801) }\end{array}$ & Percentage \\
\hline Present & $>47.5$ & 215 & $26.84 \%$ \\
\hline absent & $<47.5$ & 586 & $73.16 \%$ \\
\hline Diagnosis/ caseness & $\begin{array}{c}\text { Criteria based on } \\
\text { score }\end{array}$ & $\begin{array}{c}\text { Number } \\
\text { (Total =801) }\end{array}$ & Percentage \\
\hline Case of anxiety & $>11$ & 109 & $13.6 \%$ \\
\hline Borderline case & $8-11$ & 182 & $22.72 \%$ \\
\hline normal & $<7$ & 510 & $63.67 \%$ \\
\hline & & & \\
\hline Diagnosis/ caseness & Criteria based on & Number & Percentage \\
\hline Case of depression & $>11$ & 50 & $6.24 \%$ \\
\hline Borderline case & $8-11$ & 132 & $16.48 \%$ \\
\hline normal & $<7$ & 619 & $77.28 \%$ \\
\hline
\end{tabular}

*Out of the total participants 215(26.84\%) were found to have adjustment disorder, 586(73.16\%) were not found to have adjustment disorder. 109(13.6\%) were found to have anxiety disorder,182(22.7\%) were found to be borderline case,510(63.7\%) were found to be normal. 50(6.24\%) were found to have depression disorder,132(16.48\%) were found to be borderline case,619(77.28) were found to be normal.

Table 3: Mean value of the scores of the three scales used in the study and the distribution in various age groups who participated in the study

\begin{tabular}{|l|c|c|c|}
\hline Score & Age & Mean & Standard deviation \\
\hline \multirow{4}{*}{ Adjustment disorder } & $18-35$ & 39.126 & 13.149 \\
\cline { 2 - 4 } & $36-50$ & 40.5 & 13.149 \\
\cline { 2 - 4 } & $51-65$ & 38.74 & 13.149 \\
\cline { 2 - 4 } & $>65$ & 34 & 13.149 \\
\hline \multirow{5}{*}{ Anxiety } & $18-35$ & 5.91 & 3.644 \\
\cline { 2 - 4 } & $36-50$ & 5.66 & 4.249 \\
\cline { 2 - 4 } & $51-65$ & 5.39 & 4.249 \\
\hline \multirow{4}{*}{ Depression } & $>65$ & 2.95 & 4.249 \\
\cline { 2 - 4 } & $18-35$ & 5.09 & 3.557 \\
\cline { 2 - 4 } & $36-50$ & 4.61 & 3.559 \\
\cline { 2 - 4 } & $51-65$ & 4.51 & 3.559 \\
\hline
\end{tabular}

* Mean value for the ADNM scale was highest for the age group of 36-50 (MEAN=40.5, $\mathrm{S}$. $\mathrm{D}=13.149)$, +whereas the mean value was highest for both anxiety and depression for the age group of 18-35 -Anxiety (MEAN=5.91, SD=4.249) and Depression (MEAN=5.09, S.D-3.559) scale of HADS.

Table 4: Shows the mean differences between males and females (Gender $\mathrm{T}$ test)

\begin{tabular}{|l|c|c|c|c|c|c|}
\hline Variable & Sex & N & Mean & SD & t & Significant \\
\hline \multirow{2}{*}{ Ajd } & Male & 368 & 38.18 & 13.149 & 81.5 & 0.029 \\
\cline { 2 - 5 } & Female & 433 & 40.25 & 13.084 & & \\
\hline \multirow{2}{*}{ Anxiety } & Male & 368 & 5.25 & 4.24 & 27.5 & 0.010 \\
\cline { 2 - 5 } & Female & 433 & 6.02 & 4.247 & & \\
\cline { 2 - 5 } & Male & 368 & 4.50 & 3.559 & 25.9 & 0.039 \\
\cline { 2 - 5 } & Female & 433 & 5.02 & 3.557 & & \\
\hline
\end{tabular}

*The mean values of ADNM 20 anxiety and depression for males were found to be $38.18,5.25,4.5$ respectively and $13.149,4.24,3.559$ as their respective standard deviation.

+The mean values of ADNM 20 anxiety and depression for females were found to be 40.25,6.02,5.02 respectively and 13.084,4.247,3.557 as their respective standard deviation.

$\$$ The means values of females were found to be higher than males.

** Significant difference was observed between males and females ADNM20 ( $\mathrm{t}=81.5, \mathrm{p}=0.0290)$, ANXIETY $(\mathrm{t}=27.5, \mathrm{p}=0.010)$, DEPRESSION $(\mathrm{t}=25.9, \mathrm{p}=0.039)$. 
Table 5: Shows the group differences on ADNM, anxiety, depression among the various occupation

\begin{tabular}{|c|c|c|c|c|c|c|}
\hline Variable & Occupation & $\mathbf{N}$ & Mean & SD & $\mathbf{F}$ & Signfnc. \\
\hline \multirow[t]{5}{*}{ Ajd } & Healthcare & 131 & 39.80 & 13.084 & \multirow{5}{*}{0.967} & \multirow[t]{5}{*}{0.425} \\
\hline & IT & 77 & 41.63 & 13.149 & & \\
\hline & Student & 210 & 38.9 & 13.084 & & \\
\hline & Homemaker & 94 & 39.76 & 13.149 & & \\
\hline & Other & 289 & 38.54 & 13.084 & & \\
\hline \multirow[t]{5}{*}{ Anxiety } & Healthcare & 131 & 5.38 & 4.247 & \multirow{5}{*}{2.427} & \multirow[t]{5}{*}{0.047} \\
\hline & IT & 77 & 6.75 & 4.249 & & \\
\hline & Student & 210 & 5.97 & 4.247 & & \\
\hline & Homemaker & 94 & 5.81 & 4.247 & & \\
\hline & Other & 289 & 5.24 & 4.247 & & \\
\hline \multirow[t]{5}{*}{ Depression } & Healthcare & 131 & 4.40 & 3.557 & \multirow{5}{*}{3.994} & \multirow[t]{5}{*}{0.003} \\
\hline & IT & 77 & 5.64 & 3.559 & & \\
\hline & Student & 210 & 5.26 & 3.559 & & \\
\hline & Homemaker & 94 & 5.06 & 3.559 & & \\
\hline & Other & 289 & 4.30 & 3.557 & & \\
\hline
\end{tabular}

*On ADNM20 scale the mean values were 39.80,41.63,38.9,39.76,38.54 for healthcare, IT, student, homemaker, others respectively and their respective standard deviation were 13.084,13.149,13.084,13.149,13.084. No significant difference was observed among the different occupation on ADNM20(F=0.967, $\mathrm{p}=0.425)$, + On ANXIETY scale the mean values were 5.38,6.75,5.97,5.81,5.24 for healthcare, IT, student, homemaker, others respectively and their respective standard deviation were 4.247,4.249,4.247,4.247,4.247. A significant group difference was observed among the different professionals on ANXIETY scale $(\mathrm{F}=2.427, \mathrm{p}=0.047)$.

\$ On DEPRESSION scale the mean values were 4.40,5.64,5.26,5.06,4.30 for healthcare, IT, student, homemaker, others respectively and their respective standard deviation were 3.557,3.559,3.559,3.559,3.557. A significant group difference was observed among the different professionals on DEPRESSION $(\mathrm{F}=3.994, \mathrm{p}=0.003)$.

\# Further a post hoc comparison of the group was done using LSD.

**In the anxiety scale post hoc revealed a significant difference between healthcare and IT $(\mathrm{Md}=1.364, \mathrm{p}=0.025)$ and IT and another group $(\mathrm{Md}=1.508, \mathrm{p}=0.006)$. No significant difference was observed among other groups. In depression scale post hoc revealed a significant difference between health care and $\mathrm{IT}(\mathrm{Md}=1.245, \mathrm{p}=0.014)$ and IT and other group (Md=1.348,p=0.003), healthcare and students $(\mathrm{Md}=0.857, \mathrm{p}=0.030)$. No significant difference was observed among other groups.

Table 6 shows the differences in adjustment (ADNM), anxiety and depression scores among people who had given different responses for the question "Of the time spent on television and social media, how much time do you spend watching news, posts, write up, videos and programmes related to corona virus",

Table 6: Anova comparing the scores of ADNM-20, HADS among the various responses to the time spent on watching corona related programmes on TV

\begin{tabular}{|c|c|c|c|c|c|c|}
\hline $\begin{array}{l}\text { Variable } \\
\end{array}$ & Time on TV related to Corona Virus & $\mathbf{N}$ & Mean & SD & $\mathbf{F}$ & Signfnc. \\
\hline \multirow[t]{5}{*}{ ADNM Score } & Minimum & 416 & 38.18 & 13.084 & \multirow[t]{5}{*}{2.937} & \multirow[t]{5}{*}{.019} \\
\hline & Most & 172 & 41.61 & 13.149 & & \\
\hline & Less than half & 130 & 38.49 & 13.084 & & \\
\hline & More than half & 77 & 41.06 & 13.149 & & \\
\hline & Whole time & 6 & 45.83 & 13.084 & & \\
\hline \multirow[t]{5}{*}{ Anxiety } & Minimum & 416 & 5.26 & 4.247 & \multirow[t]{5}{*}{2.786} & \multirow{5}{*}{.026} \\
\hline & Most & 172 & 6.35 & 4.247 & & \\
\hline & Less than half & 130 & 5.86 & 4.247 & & \\
\hline & More than half & 77 & 5.81 & 4.247 & & \\
\hline & Whole time & 6 & 8.33 & 4.247 & & \\
\hline \multirow[t]{5}{*}{ Depression } & Minimum & 416 & 4.52 & 3.557 & \multirow[t]{5}{*}{2.070} & \multirow[t]{5}{*}{.083} \\
\hline & Most & 172 & 5.44 & 3.559 & & \\
\hline & Less than half & 130 & 4.8 & 3.557 & & \\
\hline & More than half & 77 & 4.67 & 3.559 & & \\
\hline & Whole time & 6 & 5.33 & 3.557 & & \\
\hline
\end{tabular}

*A significant group difference was observed in adjustment (ADNM) $(\mathrm{F}=2.973, \mathrm{P}=0.019)$ and anxiety $(\mathrm{F}=2.786, \mathrm{P}=0.026)$. + Further post hoc analysis among the groups was done using LSD. It showed a significant difference IN ADNM20 between "minimum time" and "most of the time" ( $\mathrm{Md}=3.425, \mathrm{p}=0.004)$ and between "most of the time and "less than half of the time" $(\mathrm{Md}=3.118, \mathrm{p}=0.04)$. \$ Further between groups 'minimum time spent" and 'most of the time spent.' post hoc comparison was significant in both' anxiety $(\mathrm{Md}=1.093, \mathrm{p}=0.004)$ and depression $(\mathrm{Md}=0.0913, \mathrm{p}=0.005)$. 
Table 7: Behaviours that increased during lockdown

\begin{tabular}{|c|c|c|c|}
\hline Behaviours that were increased during lockdown & Categories & Percentage & Actual numbers \\
\hline \multirow{2}{*}{$\begin{array}{l}\text { During lockdown, how much time do you spend on Social } \\
\text { media and } \\
\text { television }\end{array}$} & $<4$ & $44.3 \%$ & 354 \\
\hline & $4-8$ & $41.1 \%$ & 329 \\
\hline \multirow[t]{2}{*}{ Total $=801$} & $8-12$ & $11.7 \%$ & 93 \\
\hline & $>12$ & & \\
\hline \multirow{2}{*}{$\begin{array}{l}\text { Would you say that you spend more time pursuing your } \\
\text { hobbies now than before the lockdown }\end{array}$} & Yes & $45.1 \%$ & 361 \\
\hline & No & $31.5 \%$ & 252 \\
\hline Total $=801$ & Maybe & $23.5 \%$ & 188 \\
\hline \multirow{3}{*}{$\begin{array}{l}\text { Would you say that you are working out/ exercising more } \\
\text { than what you did before lockdown }\end{array}$} & Yes & $29.8 \%$ & 238 \\
\hline & No & $44.3 \%$ & 358 \\
\hline & May be & $14.6 \%$ & 116 \\
\hline Total $=801$ & I don't exercise & $11.2 \%$ & 89 \\
\hline \multirow{3}{*}{$\begin{array}{l}\text { Do you feel that you are more involved in household chores } \\
\text { after lockdown }\end{array}$} & Yes & $64.7 \%$ & 518 \\
\hline & No & $18.2 \%$ & 145 \\
\hline & May be & $15 \%$ & 120 \\
\hline Total $=801$ & $\begin{array}{l}\text { Prefer not to } \\
\text { involve }\end{array}$ & $2.1 \%$ & 18 \\
\hline
\end{tabular}

*When compared to before people spent more time on TV and social media during lockdown

$+361(45.1 \%)$ said yes for spending more time pursing their hobbies now than before the lockdown

$\$ 238(29.8 \%)$ people said yes for spending more time for exercising,

** 518(64.7\%) said yes for spending more time on doing chores,

\section{Which of the following habits have increased in frequency since the lock down?}

801 responses

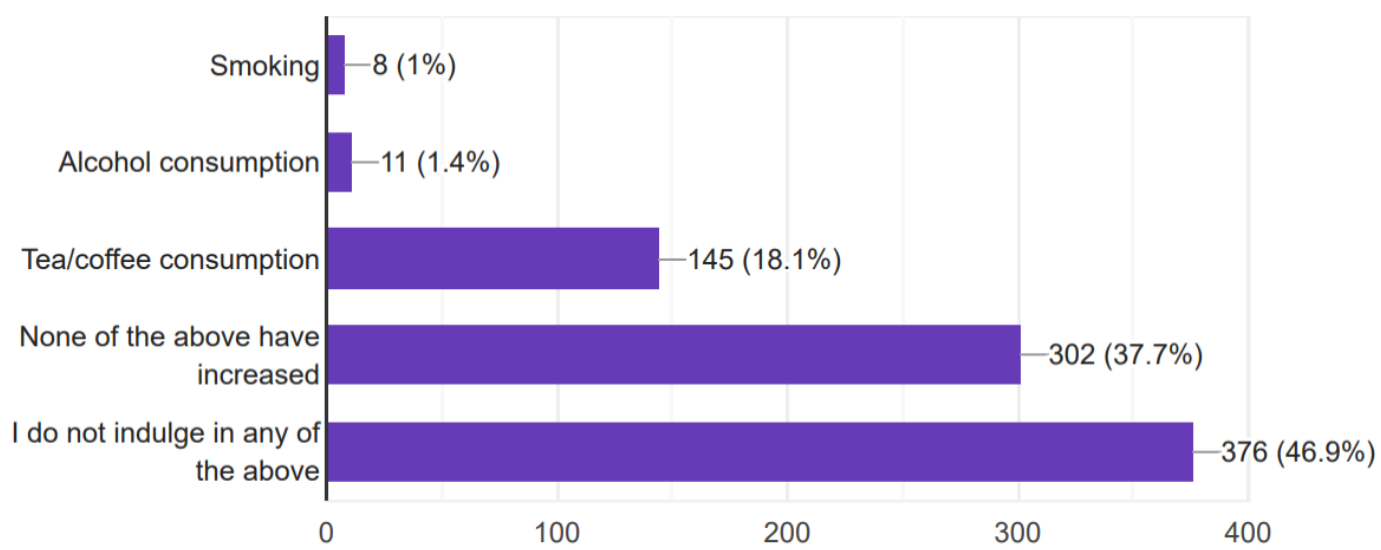

Fig. 1: Showing the frequency of various habits during lockdown

When enquired about the habits that had increased during lockdown, * $8(0.99 \%)$ people were smoking, $11(1.37 \%)$ people were consuming alcolol, 145(18.1\%) people were having tea/coffee, 302(37.7\%) people were none increased,376(46.9\%) people were with no indulgence 
Table 8: Shows the association between financial worries of the people due to sudden imposition of lockdown with Adjustment disorder, anxiety and depression

\begin{tabular}{|c|c|c|c|c|c|c|}
\hline Character & \multirow[t]{2}{*}{ Response category } & \multicolumn{3}{|c|}{ Adjustment disorder } & Chi square & $P$ value \\
\hline \multirow{8}{*}{ Finance } & & $\begin{array}{c}\text { Present } \\
>47.5\end{array}$ & $\begin{array}{c}\text { Absent } \\
<47.5\end{array}$ & Total & \multirow[t]{8}{*}{28.128} & \multirow[t]{8}{*}{0.0001} \\
\hline & \multirow[t]{2}{*}{ Yes } & 106 & 176 & 282 & & \\
\hline & & $37.58 \%$ & $62.41 \%$ & $100 \%$ & & \\
\hline & \multirow[t]{2}{*}{ No } & 47 & 215 & 262 & & \\
\hline & & $17.93 \%$ & $82.06 \%$ & $100 \%$ & & \\
\hline & \multirow{2}{*}{$\begin{array}{l}\text { Not much but I do think about } \\
\text { it }\end{array}$} & 62 & 195 & 257 & & \\
\hline & & $24.12 \%$ & $75.87 \%$ & $100 \%$ & & \\
\hline & Total & 215 & 586 & 801 & & \\
\hline
\end{tabular}

\begin{tabular}{|c|c|c|c|c|c|c|c|}
\hline \multirow[t]{2}{*}{ Character } & \multirow[t]{2}{*}{ Response category } & \multicolumn{4}{|c|}{ Anxiety disorder based on HADS score } & \multirow{2}{*}{$\begin{array}{c}\begin{array}{c}\text { Chi } \\
\text { square }\end{array} \\
50.252\end{array}$} & \multirow{2}{*}{$\begin{array}{l}\text { P value } \\
0.0001\end{array}$} \\
\hline & & $\begin{array}{l}\text { Case } \\
>11\end{array}$ & $\begin{array}{l}\text { Borderline } \\
\text { case } 8-10\end{array}$ & Normal & Total & & \\
\hline & \multirow[t]{2}{*}{ Yes } & 61 & 85 & 136 & 282 & & \\
\hline & & $21.63 \%$ & $30.14 \%$ & $48.22 \%$ & $100 \%$ & & \\
\hline \multirow[t]{4}{*}{ Finance } & \multirow[t]{2}{*}{ No } & 25 & 41 & 196 & 262 & & \\
\hline & & $9.54 \%$ & 15.64 & $74.8 \%$ & $100 \%$ & & \\
\hline & \multirow{2}{*}{$\begin{array}{l}\text { Not much but I do } \\
\text { think about it }\end{array}$} & 23 & 56 & 178 & 257 & & \\
\hline & & $8.94 \%$ & $21.78 \%$ & $69.26 \%$ & $100 \%$ & & \\
\hline & Total & 109 & 182 & 510 & 801 & & \\
\hline
\end{tabular}

\begin{tabular}{|c|c|c|c|c|c|c|c|}
\hline Character & Response category & Depres & disorder $b$ & d on HA & score & Chi & P value \\
\hline \multirow[t]{7}{*}{ Finance } & & $\begin{array}{l}\text { Case } \\
>11\end{array}$ & $\begin{array}{l}\text { Borderline } \\
\text { case } 8-10\end{array}$ & Normal & Total & \multirow[t]{8}{*}{16.661} & \multirow[t]{8}{*}{0.002} \\
\hline & \multirow[t]{2}{*}{ Yes } & 19 & 66 & 197 & 282 & & \\
\hline & & $6.7 \%$ & $23.4 \%$ & $69.85 \%$ & $100 \%$ & & \\
\hline & \multirow[t]{2}{*}{ No } & 15 & 30 & 217 & 262 & & \\
\hline & & $5.72 \%$ & $11.45 \%$ & $82.06 \%$ & $100 \%$ & & \\
\hline & \multirow{2}{*}{$\begin{array}{l}\text { Not much but I do } \\
\text { think about it }\end{array}$} & 16 & 36 & 205 & 257 & & \\
\hline & & $6.22 \%$ & $14 \%$ & $79.76 \%$ & $100 \%$ & & \\
\hline & Total & 50 & 132 & 619 & 801 & & \\
\hline
\end{tabular}

*When enquired among 801 people what was their financial status or else whether they had any financial crisis during lockdown, 282(35.2\%) said yes, 262(32.7\%) said no, 257(32.08\%) said that they didn't have much financial crisis but they consider that +A significant association was found between the various responses about financial worries and adjustment disorder (chi square value $=28.128, \mathrm{p}=0.0001)$.

$\$$ Varying severity of anxiety (chi square value $=50.252, \mathrm{p}=0.0001$ ) and varying severity of depression (chi square value $=16.661$, $\mathrm{p}=0.002$ ) were also found to be significantly associated with financial worries.

Table 9 shows various response of people to whether they had fight with a family member during the sudden prolonged confinement within their homes due to the sudden imposition of the lockdown and their association with Adjustment disorder, Anxiety and Depression 
Table 9: Table showing the association between fight with adjustment disorder, anxiety and depression

\begin{tabular}{|c|c|c|c|c|c|c|}
\hline \multirow[t]{2}{*}{ Character } & \multirow[t]{2}{*}{ Response category } & \multicolumn{3}{|c|}{ Adjustment disorder } & \multirow{2}{*}{$\begin{array}{c}\text { CHI } \\
\text { square }\end{array}$} & \multirow[t]{2}{*}{ P value } \\
\hline & & $\begin{array}{c}\text { Present } \\
>47.5\end{array}$ & $\begin{array}{c}\text { Absent } \\
<47.5\end{array}$ & Total & & \\
\hline \multirow{7}{*}{ Fight } & \multirow[t]{2}{*}{ Yes } & 76 & 75 & 151 & \multirow[t]{7}{*}{64.328} & \multirow[t]{7}{*}{0.0001} \\
\hline & & $50.3 \%$ & $49.66 \%$ & $100 \%$ & & \\
\hline & \multirow[t]{2}{*}{ No } & 95 & 423 & 518 & & \\
\hline & & $18.33 \%$ & $81.66 \%$ & $100 \%$ & & \\
\hline & \multirow[t]{2}{*}{ May be } & 44 & 88 & 132 & & \\
\hline & & $33.3 \%$ & $66.6 \%$ & $100 \%$ & & \\
\hline & Total & 215 & 586 & 801 & & \\
\hline
\end{tabular}

\begin{tabular}{|c|c|c|c|c|c|c|c|}
\hline \multirow[t]{2}{*}{ Character } & \multirow{2}{*}{$\begin{array}{l}\text { Response } \\
\text { category }\end{array}$} & \multicolumn{4}{|c|}{ Anxiety disorder based on HADS score } & \multirow{2}{*}{$\begin{array}{c}\text { Chi } \\
\text { square }\end{array}$} & \multirow{2}{*}{$\begin{array}{c}\mathbf{P} \\
\text { value }\end{array}$} \\
\hline & & Case $>11$ & $\begin{array}{c}\text { Borderline } \\
\text { case } 8-10\end{array}$ & normal & total & & \\
\hline \multirow{7}{*}{ Fight } & \multirow[t]{2}{*}{ Yes } & 46 & 45 & 60 & 151 & 78.089 & 0.0001 \\
\hline & & $30.46 \%$ & $29.8 \%$ & $39.73 \%$ & $100 \%$ & & \\
\hline & \multirow[t]{2}{*}{ No } & 46 & 93 & 379 & 518 & & \\
\hline & & $8.8 \%$ & $17.9 \%$ & $73.16 \%$ & $100 \%$ & & \\
\hline & \multirow[t]{2}{*}{ May be } & 17 & 44 & 71 & 132 & & \\
\hline & & $12.87 \%$ & $33.3 \%$ & $53.7 \%$ & $100 \%$ & & \\
\hline & Total & 109 & 182 & 510 & 801 & & \\
\hline \multirow[t]{2}{*}{ Character } & $\begin{array}{c}\text { Response } \\
\text { category }\end{array}$ & \multicolumn{4}{|c|}{ Depression disorder based on HADS score } & $\begin{array}{c}\text { Chi } \\
\text { square }\end{array}$ & $\begin{array}{c}\mathbf{P} \\
\text { value } \\
\end{array}$ \\
\hline & & Case $>11$ & $\begin{array}{c}\text { Borderline } \\
\text { case } 8-10\end{array}$ & Normal & total & & \\
\hline \multirow{7}{*}{ Fight } & \multirow[t]{2}{*}{ Yes } & 20 & 47 & 84 & 151 & 54.667 & 0.0001 \\
\hline & & $13.24 \%$ & $31.12 \%$ & $55.62 \%$ & $100 \%$ & & \\
\hline & \multirow[t]{2}{*}{ No } & 20 & 63 & 435 & 518 & & \\
\hline & & $3.86 \%$ & $12.16 \%$ & $83.9 \%$ & $100 \%$ & & \\
\hline & \multirow[t]{2}{*}{ May be } & 10 & 22 & 100 & 132 & & \\
\hline & & $7.57 \%$ & $16.6 \%$ & $75.7 \%$ & $100 \%$ & & \\
\hline & Total & 50 & 132 & 619 & 801 & & \\
\hline
\end{tabular}

*. When enquired among 801 people that how many of them had fight with a family member during lockdown, $151(18.85 \%)$ said yes, 518(64.67\%) said no,132(16.48\%) said maybe.

+A significant association was found between "picking up of fight with a family member" and adjustment disorder (chi square value $=64.328, \mathrm{p}=0.0001$,

$\$$ Varying severity of anxiety (chi square value $=78.089, \mathrm{p}=0.0001$ ) and depression (chi square value $=54.667, \mathrm{p}=0.0001$ ) were also found to be significantly associated with picking up a fight with a family member.

\section{Discussion}

Data was collected from various sections of people in Chennai. The main aim was to assess the immediate psychological response of people, to the sudden announcement of lockdown by the government, in the initial phase of Corona spread in India. We wanted to analyse the mental status of the people as to how they suffered to cope with the sudden changes in their lifestyle that was imposed upon them, in the face of uncertainty, due to the lockdown. Out of the total participants $26.84 \%$ were found to have adjustment disorder, $13.6 \%$ were found to have anxiety disorder, $22.7 \%$ were found to be borderline case of anxiety, $6.24 \%$ were found to have depression disorder, $16.48 \%$ were found to be borderline case of depression. This finding is in line with the Northern Spain study ${ }^{10}$ by Niara Ozamizetcibarriain which more than a quarter of the participants have reported symptoms of depression $(27.5 \%)$, anxiety $(26.9 \%)$ and stress $(26.5 \%)$ and also the Spanish study $^{11}$ by Rocio Rodreguezrey in which $59.1 \%$ showed normal levels, $11.4 \%$ showed mild depression, $14.8 \%$ showed moderate depression, $6.3 \%$ showed severe depression, $8.5 \%$ showed extremely severe depression.

In our study, mean value for the ADNM scale was highest for the age group of 36-50, and the mean value was highest for the age group of 18-35 in both Anxiety and Depression scales. Similarly, greater symptomatology was found in younger population in the study done in Northern Spain $^{10}$ by Naiara Ozamizetxebarria. These findings could 
be explained by the fact that both these age groups combined comprise most of the working population of Chennai. Sudden imposition of work from home by their respective companies due to the lockdown, drew many of these people, to experience burnout and psychological distress.

The mean scores of all the scales were found to be higher for females than males, similar to the INDIAN study published in the Community Mental Health Journal ${ }^{12}$ by Usama Rehman in which females had higher mean values of stress. This may be due to the fact that females were all the time involved in household chores during the lockdown, without any break, that they enjoyed, before the lockdown. This was due to multitude of factors like- schools and workplaces were shut and all people of the household were at home 24/7, the social norm in Chennai that women are expected to cater to the needs of their family members and lack of help from their maids or cooks who were not available during the lockdown.

A significant group difference was observed among the different occupations, on anxiety \& depression, similar to the INDIAN study published in the Community Mental Health Journal ${ }^{12}$ by Usama Rehman, in which significant group difference was found among various occupation in stress, anxiety and depression. In our study, there was significant difference in anxiety and depression score between IT and healthcare. The healthcare people had lesser scores when compared to IT. This could be explained by the fact that healthcare workers would be better equipped with scientific information regarding the covid19 virus and the spread of the illness, which helped them to take the necessary precautions without getting much stressed, compared to the IT people who were loaded with data from various sources which only confused them. In our study IT people had the highest mean score for all the three scales, this could be because of the immediate effects of lockdown like a pay-cut, sudden drop in income or freelance work disappearing overnight. Worrying about losing job is a much bigger concern than loss of income. The loss of identity, both as a professional and perhaps as the family breadwinner could have been the contributing factor for their distress.

In this study we clearly see that the ADNM, Anxiety and Depression scores increased linearly with the increase in exposure to news related to CORONA. This is in line with various studies conducted after previous natural disasters and mass events. Several hours of daily media exposure during the Ebola outbreak in 2014 increased the distress and worry of people and decreased their functioning. ${ }^{16}$ Similarly, In comparison to people who were at the actual site of the bombings, acute stress symptoms were higher among people who had more media exposure, during the Boston bombings. ${ }^{17}$ This could be explained by the fact that watching the negative and horrific news all day will activate our sympathetic nervous system and can lead to problems in our physical and mental health

As far as, the way in which the excess time was spent, When compared to before lockdown, people in our study, seem to have spent more time on TV and social media during lockdown, similar to a study done in $\operatorname{Spain}^{13}$ by Ruben Lopez Bueno in which spending time in front of TV and computers was the only habit that increased during lockdown. Majority of people said Most of their time was spent on hobbies. In the West Bengal study ${ }^{14}$ by Kaustav Charaborthy, people reported to be engaged in the following hobbies during lockdown-reading books-3.3\%, listening to music $-12.8 \%$, painting- $0.9 \%$.

Nearly half of our study population was spending their time on Exercising during the lockdown, Like the Chinese study ${ }^{15}$ by Zhang $-59.7 \%$ reported that much of their time was spent in doing exercises. In our study, 518(64.7\%) people admitted that they were more involved in household chores after lockdown. Similar to the West Bengal study ${ }^{14}$ by Kaustav Charaborthy, in which $62.9 \%$ said they were doing household chores. This increase could be because, as the lockdown began, housing Societies in Chennai banned cooks, maids and plumbers as possible carriers of the virus. So the burden of the house hold chores had to be borne by the people, who also saw it, as a good pass time, to beat the boredom.

In our study, the habits that increased during lockdown were smoking $8(0.99 \%)$, alcohol 11(1.37\%), 145(18.1\%) people were having tea/coffee. This is in contrast to the study in Spain ${ }^{13}$ by Ruben Lopes Bueno in which it was reported that alcohol, tobacco progressively decreased during COVID-19 confinement in Spain. This increase in these habits in our study could be explained by the boredom, lack of social contacts, loss of daily structure, lack of reward after a hard working day, loneliness that people were made to go through during the lockdown.

People who had financial worries were found to have adjustment disorder, anxiety and depression. This is line with the online study conducted by the IIM Lucknow ${ }^{18}$ by Satyabushan das in March 2020 in which, majority of study population were worried about the financial implications of the pandemic rather than their health due to which People felt more fearful and sad People who fought with a family member were found to have Adjustment disorder, Anxiety and Depression. In the West Bengal study ${ }^{14}$ by Kausthav Chakarbarthy $-37.1 \%$ were more irritable during lockdown. During the lockdown period in Chennai, even minor arguments $\mathrm{m}$ had couples fighting over issues such as women doing all the household chores, excessive use of mobile phones and altered behaviour due to alcohol withdrawal.

In our study females were found to have more anxiety and depression and also scored high on ADNM-20 scale. Also, we found that these scores were high for people who admitted having" picked up a fight with family members". This is explained by the alarmingly high number of domestic violence cases reported in Chennai during the lockdown. Complaints received by the National Commission for Women $(\mathrm{NCW})^{19}$ during the lockdown from March 24 to May 31, in numbers, was, 45 in Chennai,257in Coimbatore, 105in Tirupur. Women in Tamil Nadu, compared to those in other states, since a 
long time, have accepted violence against them and perceive it as normal. $86 \%$ of women, do not complain though they were abused, $77 \%$ women hide that any abuse happened. These alarming statistics explains the results of our study. Financial crisis, Job insecurity and increasing family burden superadded to substance abuse could have contributed to the alarming rise in incidence of domestic violence.

\section{Conclusion}

Our study found the behavioural adaptation of various social groups in Chennai. Our study also highlighted a few positive aspects of the lockdown. This study findings will prompt the policymakers, to intervene and prioritize mental health resources and substance use services, as these will be needed on a longer term from now. Domestic violence incidents that increased in Chennai during the lockdown have been highlighted in our study. As the pandemic spread, another problem that spread across the world was that of domestic violence, which made a lot of people suffer in silence inside their homes, making the United Nations describe the situation as Double Pandemic.

\section{Recommendations}

Public should select one or two trusted sources (such as the, Centres for Disease Control, World Health Organization) to stay updated, limit monotonous exposure to media stories on death due to corona, and ignore reports on social media whose authenticity cannot be ensured. People should watch good news of people recovering and returning home to develop HOPE, as recommended by WHO. Everyone in the family and community should be sensitised enough to intervene if they suspect an incident of domestic violence. If we do not intervene when an incident happens, the lockdown will reinforce the patriarchal institution of violence against women again. Governments should prioritize mental health as much as contact tracing and personal protective measures. Authentic information should be easily available to the public along with easy access to mental health professionals through telepsychiatry.

Trying to distract ourselves from the overload of corona news and getting involved with music, books, dance and watching programs on TV and on OTT platforms, may help to keep ourselves occupied with peace of mind.

\section{Limitations}

The study sample is limited, non-inclusive, and nonrepresentative of the population of Chennai at large. The respondents who do not have an access to the Internet like the people who reside in remote areas and the lesser privileged who didn't have a smart phone with WhatsApp, were not included in the study.

\section{Source of Funding}

None.

\section{Conflicts of Interest}

There are no conflicts of interest.

\section{References}

1. Last JM, editor. A dictionary of epidemiology, 4th edition. New York: Oxford University Press; 2001.

2. https://www.google.com/covid19-map/

3. https://www.who.int/dg/speeches/detail/who-directorgeneral-s-opening-r emarks-at-the-media-briefing-on-covid19---11-march-2020

4. Measuring the ICD-11 adjustment disorder concept: Validity and sensitivity to change of the Adjustment Disorder - New Module questionnaire in a clinical intervention study. Int J Methods Psychiatr Res. 2017;26(4).

5. Usher K, Durkin J, Bhullar N. The COVID-19 pandemic and mental health impacts. Int $J$ Ment Health Nurs. 020;29(3):315-8.

6. Sarafraz MR, Shahvand MR, Zarea T. Psychometric properties of Adjustment Disorder New Model-20 (ADNM20). J Clin Psychol. 2018;9(4).

7. Lorenz L, Bachem RC, Maercker A. The Adjustment Disorder-New Module 20 as a Screening Instrument: Cluster Analysis and Cut-off Values. Int J Occup Environ Med. 2016;7(4):215-20.

8. Moser C, Bachem R, Berger T, Maercker A. ZIEL: InternetBased Self-Help for Adjustment Problems: Results of a Randomized Controlled Trial. 2019;8(10):1655.

9. Aseri ZA, Suriya MO, Hassan HA, Hasan M, Sheikh SA. Reliability and validity of the hospital anxiety and depression scale in an emergency department in Saudi Arabia: a cross-sectional observational study. BMC Emerg Med. 2015. doi:10.1186/s12873-015-0051-4.

10. Ozamiz-Etxebarria N, Mondragon NI, Santamaría MD, Gorrotxategi MP. Psychological symptoms during the two stages of lockdown in response to the covid-19 outbreak: An investigation in a sample of citizens in Northern Spain. Front Psychol. 2020;11:1491.

11. Rodreguezrey R, Garridohernansaiz H, Collado S Psychological Impact and Associated Factors During the Initial Stage of the Coronavirus (COVID-19) Pandemic Among the General Population in Spain. Front Psychol. 2020;11:1540.

12. Rehman U, Shahnawaz MG, Khan N, Kharshiing KD, Khursheed M, Gupta K, et al. Depression, Anxiety and Stress Among Indians in Times of Covid-19 Lockdown. Community Ment Health J. 2021;57(1):42-8.

13. López-Bueno R, Calatayud J, Casaña J, Casajús JA, Smith L, Tully MA, et al. COVID-19 Confinement and Health Risk Behaviors in Spain. Front Psychol. 2020;11. doi:10.3389/fpsyg.2020.01426.

14. Chakaraborty K, Chatterjee M. COVID 19 pandemic in general population in West Bengal. Indian J Psychiatry. 2020;62(3):266-72.

15. Zhang Y, Ma ZF. Impact of the COVID-19 Pandemic on Mental Health and Quality of Life among Local Residents in Liaoning Province, China: A Cross-Sectional Study. Int J Environ Res Public Health. 2020;17(7):2381.

16. Kilogo DK, Yoo J, Johnson TJ. Spreading Ebola Panic: Newpaper and Social media coverage of the 2014 Ebola health crisis. Health Commun. 2019;34(8):811-7.

17. Marshall RD, Bryant RA, Amsel L, Suh EJ, COOK JM, Neria Y. The Psychology of ongoing threat: Relative risk appraisal, the September 11 attacks, and terrorism -related fears. Am Psychol. 2007;62(4):304-36.

18. Dash S, Jain A. Understanding public sentiment during lockdown. https://www.theweek.in/news/biztech/2020/05/24/people-more-worried-about-economiccrisis-than-coronavirus-says-study-html

19. http://ncwapps.nic.in/frmComp_stat_Overview.aspx

20. Khandelwal T. Violence agains women: A state level Analysis in India; https://ssi.edu.in/wp- 
content/uploads/2019/05/Internship-Report-by-Ms.-TanishaKhandelwal.pdf

21. https://www.thehindu.com/data/data-domestic-violencecomplaints-at-a-10-year-high-during-covid-19-

lockdown/article

22. Das S. Mental Health and Psychosocial Aspects of COVID19 in India: The Challenges and Responses; 2020. https://doi.org/10.1177\%2F0972063420935544

23. Harvard 2020; Health and well being during COVID-19India; https://www.hsph.harvard.edu/india-center/healthand-well-being-during-covid-19/

24. https://www.livemint.com/news/india/govt-issuesguidelines-for-managing-mental-illness-amid-coronaviruspandemic-11604240603627.html

25. https://scroll.in/article/977451/in-india-coronavirus-crisishas-been-particularly-hard-for-mental-health-patients-andhospitals

How to cite this article: Monicka K, Ganesh N, Nithya SP. A cross sectional study on the immediate response and mental health of the people during the initial phase of covid-19 lockdown in Chennai. Telangana J Psychiatry. 2020;6(2):143-152. 